\title{
MEETING CHILDREN'S SPECIAL EDUCATIONAL NEEDS IN SCHOOL. A LITHUANIAN CASE
}

\author{
Algirdas Alisauskas, \\ Stefanija Alisauskiene, \\ Lina Milteniene \\ Siauliai University, Lithuania
}

\begin{abstract}
This article is been based on the research with the aim to reveal the features of pedagogical and special pedagogical support for pupils with special educational needs (SEN) as well as to assess the demand for changes in the mentioned field on the ground of the survey of Lithuanian pedagogues and professionals (in all 1518 respondents). The number of children with SEN educating in mainstream schools is increasing, however, not only involvement of pupils having diverse needs (including those having SEN) into mainstream education is important, but also qualitative analysis of the educational process and content too. The analysis of highlighted character of implementation of pedagogical and special pedagogical support as well as the demand for changes showed the main focuses for improvement: support to child in a classroom decreasing exclusion, involving other participants (peers, parents, volunteers etc.), using flexible models and strategies of support.

Keywords: inclusive education, pedagogical support, special educational needs, special pedagogical support.
\end{abstract}

\section{Introduction}

During recent decades, various countries have been undergoing the change of educational paradigms. When foreseeing priority directions and strategic plans for the development of education, the UNESCO recommendations are focused on; the latter encourage governments and designers of national strategies of different countries to treat inclusive education as a priority aim in education (UNESCO, 2009a). Inclusive education increases accessibility of the educational system to each child, adolescent and adult, ensures equal opportunities. Inclusive education is a ceaseless process the main aim of which lies in the ensuring of quality education for all members of society, acknowledging and respecting diversity, regarding everyone's individual abilities and needs, avoiding any discrimination (according to UNESCO, 2009b). The essential precondition for inclusive education means that each pupil's educational needs should be met, everyone, despite one's abilities, language, sex, ethnicity, has an equal right to participate, develop oneself like peers. Both school and class becomes the environment exactly where each pupil can get needed support without following a preconceived approach toward child's inability, i.e. in the aspect of deficit (UNESCO, 2009b; Florian, 2009; Kershner, 2009; Terzi, 2008). In majority of European countries, the provision of inclusive education prevails (Avramidis, Bayliss, Burden, 2000, Meijer, 2003, etc.), much attention is paid to perfection of inclusive education practice. 
According to Ainscow et al (2006), inclusion is related to the decrease of pupils' exclusion, when more effectively applying the educational content, changing the culture at school, ensuring more active participation in school community's life. The methodological orientation of many Western European countries towards inclusive school made impact on the systemic educational changes in Lithuania too; these changes have been established in the Law on Education of the Republic of Lithuania (2011) and other documents also regulating the meeting of pupils' special educational needs $(\mathrm{SEN})^{1,2,3,5},{ }^{2}$. In Lithuania, special education is a constituent part of the mainstream comprehensive educational system. It is aimed to practically implement inclusive education by maintaining the principles of equal opportunities and rights, accessibility, equity, quality and effectiveness of education. In this context an important role is given to school communities and teachers, i.e. it is important that they would accept the idea of (self-)transformation of school into an inclusive school and would be able to practically implement it. These ideas are reflected in research works carried out throughout recent years (Savolainen, H. et al., 2011; A. Ališauskas et al., 2011; Miltenienè, 2005, 2006; Ainscow, 2005; Ališauskienè, et al., 2004; O'Callaghan, 2000, etc.). Lithuania's way towards inclusive practice is proven by an increasing part of pupils with SEN educating in mainstream comprehensive schools: in academic year 2011-2012, 11.3\% of children having SEN were a part of comprehensive mainstream schools population of Lithuania ${ }^{6}$, most (approx. 90\%) of pupils with SEN attended common classes at mainstream comprehensive schools. Special schools and special classes were attended by approx. $10 \%$ of SEN pupils. However, not only involvement of pupils having diverse needs (including those having SEN) into mainstream education is important, but also qualitative analysis of the inclusive education process and content too. The article presents some aspects of analysis of implementation of inclusive education practice in Lithuania.

The aim of the research is to reveal the features of pedagogical and special pedagogical support for pupils with SEN as well as to assess the demand for

\footnotetext{
${ }^{1}$ Dèl mokinio specialiuju ugdymosi poreikiu (išskyrus atsirandančius dèl išskirtiniu gabumu) pedagoginiu, psichologiniu, medicininiu ir socialiniu pedagoginiu aspektais ivertinimo ir specialiojo ugdymosi skyrimo tvarkos aprašo patvirtinimo, LR ŠMM ministro įsakymas Nr. V-1775, $2011 \mathrm{~m}$. rugsèjo $30 \mathrm{~d}$

${ }^{2}$ Dél mokiniu, turinčiu specialiuju ugdymosi poreikiu, grupiu nustatymo ir ju specialiuju ugdymosi poreikiu skirstymo i lygius tvarkos aprašo patvirtinimo Valstybès žinios, 2011-07-21, Nr. 93-4428

${ }^{3}$ Dèl švietimo ir mokslo ministro $2004 \mathrm{~m}$. birželio 25 d. isakymo Nr. ISAK-1019 "Dél Prièmimo i valstybine ir savivaldybès bendrojo lavinimo, profesinio mokymo istaiga bendruju kriteriju sarašo patvirtinimo" pakeitimo Valstybès žinios: 2011-07-23 Nr.96-4533.

${ }^{4}$ Dèl Specialiosios pedagoginès pagalbos teikimo tvarkos aprašo patvirtinimo. Valstybės žinios: 2011-07-20 Nr.92-4395.

${ }^{5}$ Dèl Mokyklos vaiko gerovès komisijos sudarymo ir jos darbo organizavimo tvarkos aprašo patvirtinimo. Valstybès žinios,2011-04-13, Nr. 45-2121.

${ }^{6}$ Lietuvos švietimas skaičiais, 2012. Bendrasis ugdymas. Vilnius, ŠAC, 2012, p.28

${ }^{7}$ The research being introduced is a part of the research Diversity of Forms of Education of Persons with Special Needs (2010), A. Ališauskas, et al. (www.sppc.lt).
} 
changes in the mentioned field on the ground of the survey of Lithuanian pedagogues.

The research object is pedagogical and special pedagogical support provided at school for pupils with SEN.

\section{The research sample}

The representative survey of respondents has been carried out (not exceeding the $5 \%$ bias). The research sample consisted of 1518 pedagogues and professionals providing pedagogical and special pedagogical support. To ensure the representative sample it was aimed at a proportional amount of the surveyed to the size of a layer and that it would cover all schools of the state. The respondents were distributed according to the type of schools: secondary $(41.3 \%)$, primary $(5.6 \%)$, basic $(28.4 \%)$, gymnasium high school $(9.8 \%)$, special school (7.8\%), school-kindergarten (2.6\%), youth school (1\%), part-time (evening) school $(0.1 \%)$, sanatorium boarding school (3.4\%). The average of pedagogical work experience of those who participated in the written survey was 20.5 years. According to the sex, the respondents were the following: women $(95.7 \%)$ and men $(4.3 \%)$.

\section{The research methodology and instrument}

The research employed the methods of theoretical analysis and questionnairebased survey in a written form. The survey aimed at finding out how pedagogues and professionals providing special pedagogical support assess suitability of forms of education of pupils having SEN (education at a comprehensive mainstream school, special class of a school and a special school), character of implementation of pedagogical and special pedagogical support as well as what changes in the support are highlighted. The questionnaire has been worked out on the ground of documents of the Ministry of Education and Science of the Republic of Lithuania regulating provision of pedagogical and special pedagogical support to pupils with SEN. The questionnaire consisted of 13 diagnostic blocks and 213 features. This article deals with data of 5 diagnostic blocks (demographical data; assessment of efficiency of educational forms and their combinations; strengths and weaknesses of educational forms; fields of special pedagogical support; sharing of roles and functions meeting SEN) when emphasising assessment by pedagogues related to provision of pedagogical and special pedagogical support. The research data has been processed by applying statistical data analysis: descriptive statistics and factor-based analysis. 


\section{Analysis of the results}

This chapter presents results of the questionnaire-based survey of pedagogues revealing pedagogues' opinion on various forms of education of pupils with SEN as well as specificity of provision of pedagogical and special pedagogical support emphasising pedagogues' attitude towards suitability of educational form with regard to the level (mild, moderate, severe, very severe) of children SEN, e. g. what educational form would be the most suitable, what is the reality of education and what should be improved.

\section{Inclusive Education of Pupils with Sen}

Suitability of education according to the level of pupils' special educational needs. As majority of participants of the survey share this point of view, the form of education when children having SEN attend a class in a comprehensive mainstream school together with their peers is the most suitable for pupils having mild special educational needs ( $82 \%$ answers). Almost a half of the surveyed (45\%) hold the opinion that an inclusive school may be a place for successful education also for pupils who have moderate SEN. This form is indicated by teachers as unsuitable for children having severe and very severe SEN.

Features of pedagogical and special pedagogical support in a comprehensive mainstream school. Aiming to reveal features of pedagogical, special pedagogical support in a comprehensive mainstream school, pedagogues assessed the statements related to various fields of support, indicating real practice and assessing the demand for changes in certain fields.

Teacher's support in a classroom. When characterising teacher's support in a classroom, the respondents stated that a sufficient amount of time is dedicated to individual support for a child having SEN during a lesson. When educating a pupil, the recommendations of specialists of the School Child's Welfare Board (SCWB) and the Pedagogical Psychological Service (PPS) are followed. Aims and content of education are being discussed with a child and one's parents, a special pedagogue, speech therapist. High mean values have been recorded in assessment of both real situation and the need to consolidate the support of the mentioned field (see Figure 1).

The biggest demand for changes was recorded in the following fields: a teacher uses support of volunteers (parents, foster parents, relatives or others) in a classroom (difference between means ${ }^{8}$ is 0.68 ); a teacher flexibly arranges education in a classroom according to the need by changing the timetable

\footnotetext{
${ }^{8}$ Support or education field should be improved when, according to the respondents, assessment of a situation is lower than that of the need. This is measured by deducting means of assessment $\left(\mathrm{M}_{1}-\mathrm{M}_{2}\right)$ of a situation (proceeds) $\left(\mathrm{M}_{1}\right)$ and need (must be provided / consolidated $)\left(\mathrm{M}_{2}\right)$. The higher the negative difference is, the greater the need for support and its consolidation in a particular field. Indicated differences in assessment of the situation and demand are statistically significant $(\mathrm{p}<0.05)$.
} 
(0.43); by using the support of another teacher or specialist (special pedagogue, speech therapist) in a classroom; a teacher works individually with a SEN child after lessons are over (0.35). The need to identify and use resources was indicated as one of possibilities to develop support to a teacher in a comprehensive mainstream class (i.e. volunteering and support of professionals for a teacher in a classroom) and the need of pedagogues themselves to be more flexible when providing support to a pupil with SEN.

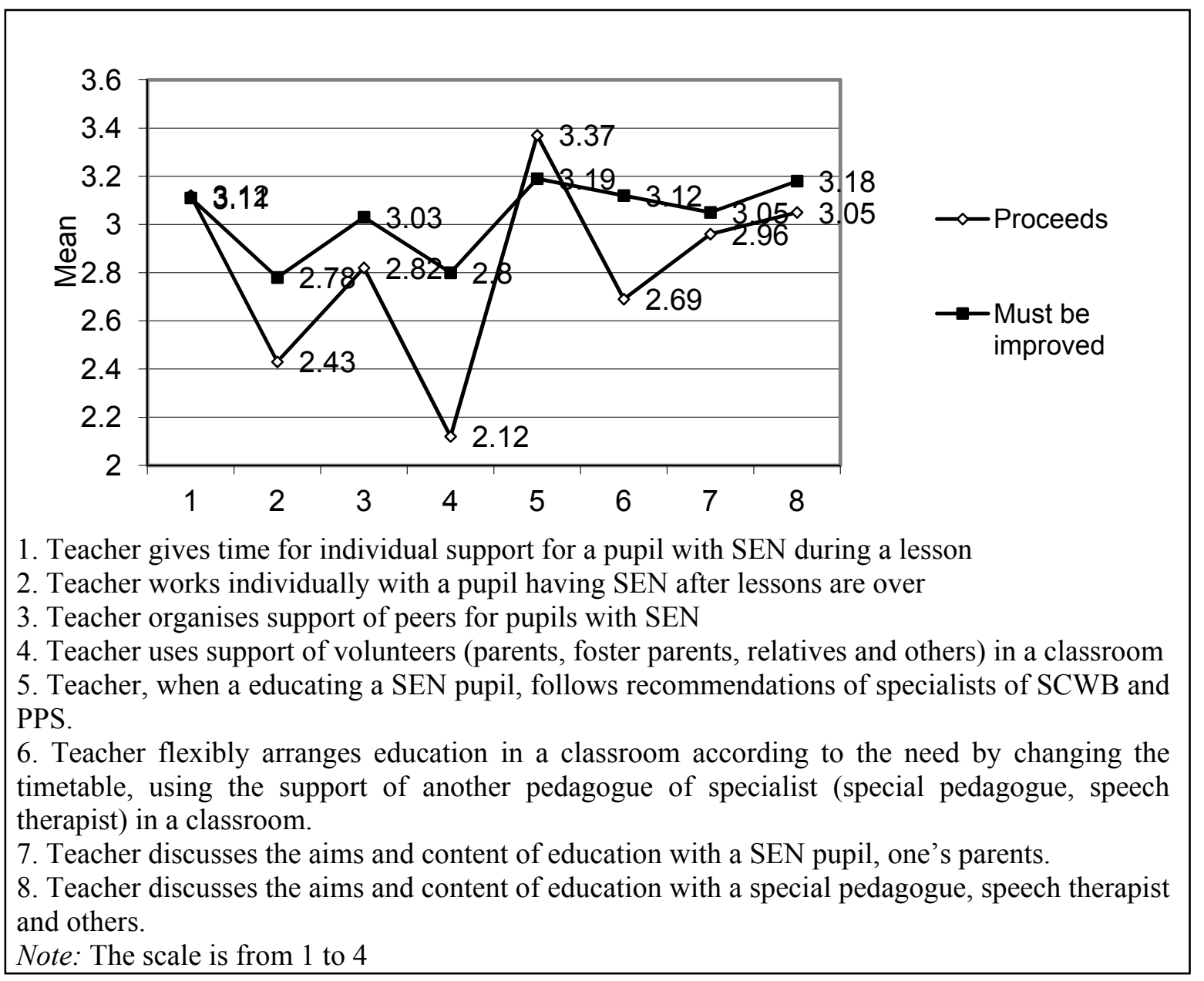

Figure 1 Features of teacher's support in a classroom of a comprehensive school

Support of special education professionals. When characterising support of a special pedagogue and speech therapist, research participants indicate that welldeveloped support of special education specialists and group support for pupils having SEN in a separate room (high mean values in both assessing a real situation and the need to consolidate the mentioned field of support; see Figure 2). 


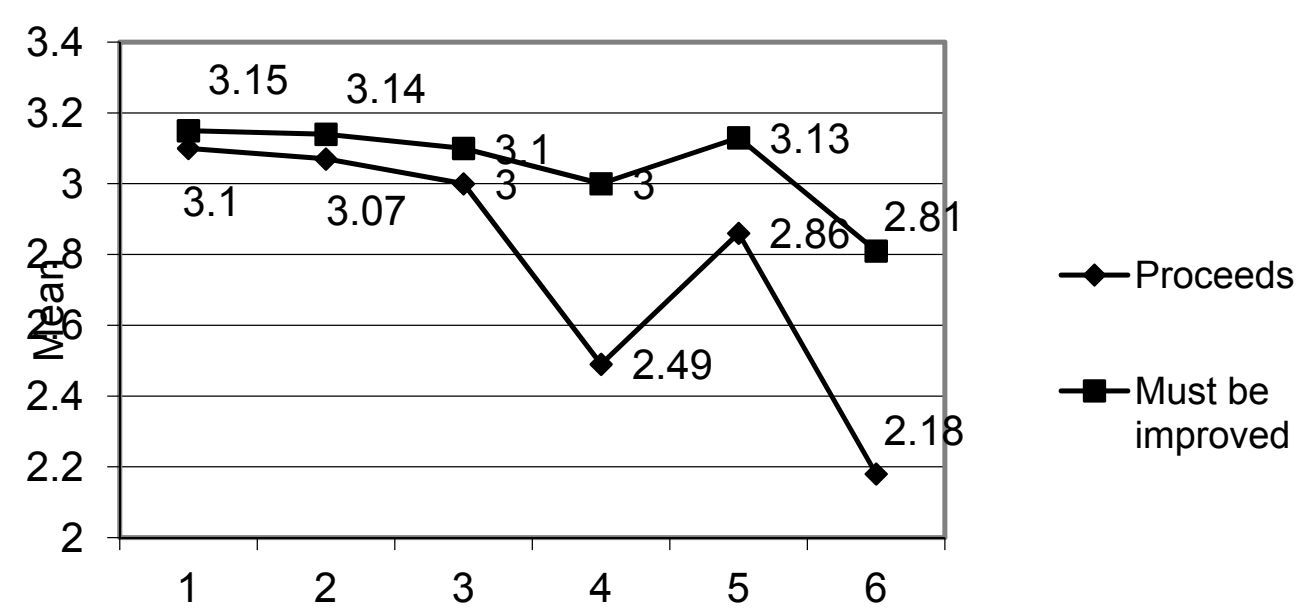

1. Specialist organises group lessons for SEN pupils in a separate room

2. Special pedagogue provide individual support in a separate room during lessons

3. Speech therapist provides individual support in a separate room not during lessons

4. Specialist provides support for SEN children during lessons in a classroom which they attend

5. Specialist flexibly changes one's forms and intensity of support depending on a situation

6. Speech therapist offers support in a classroom during lessons

Note: The scale is from 1 to 4

\section{Figure 2 Features of support of special education specialists in a comprehensive mainstream school}

The need to consolidate special pedagogical support is identified in the fields which are more related to flexibility and diversity of provision of the support when choosing models to organise support. Higher differences of means are recorded in the following fields: a speech therapist offers own support in a classroom during lessons (difference of means is 0.63); a specialist provides support to children with SEN during lessons in a classroom which they attend (0.51); a specialist flexibly changes forms and intensity of one's support depending on a situation (0.32). The results show higher demand in support for pupils in a classroom when changing strategies and models of organisation of support, more flexibly adjusting them. Present legal documents ${ }^{9}$ do not foresee the possibility for speech therapist's support during lessons; however, the need for pedagogues to closer collaborate and apply more diverse models of provision of special pedagogical support is obvious.

${ }^{9}$ Dèl Logopedu, dirbančiu mokyklose, bendrujụ pareiginių nuostatu patvirtinimo. Valstybès žinios, 2006-04-08, Nr. 39-1421. 


\section{Education of Pupils in a Special Class of a Comprehensive Mainstream School}

\section{Suitability of a form of education}

Majority of respondents expressed the opinion that this form of education is the most suitable in the cases of moderate $(46 \%$ of answers) and severe $(36 \%$ of answers) SEN. A part of them (15\% of answers) are bound to offer this form of education to children with mild SEN too. A small part ( $8 \%$ of answers) of them indicated that children who have very severe SEN could also be successfully educated in such a way. Education of children in a special class of a mainstream school can be interpreted as a striving to create classes based on the principle of homogeneity, and this is to be discussed in the point of view of the inclusive education idea.

\section{Features of pedagogical and special pedagogical support}

Teacher's support in a classroom. When characterising teacher's support in a classroom, the respondents state that special classes in mainstream schools allocate a sufficient amount of time to individual support for a child having SEN during lessons, support of peers is arranged, a teacher adjusts educational aims and content with a SEN pupil, one's parents, other specialists providing support, follows recommendations of professionals of the SCWB and the PPS (see Figure 3).

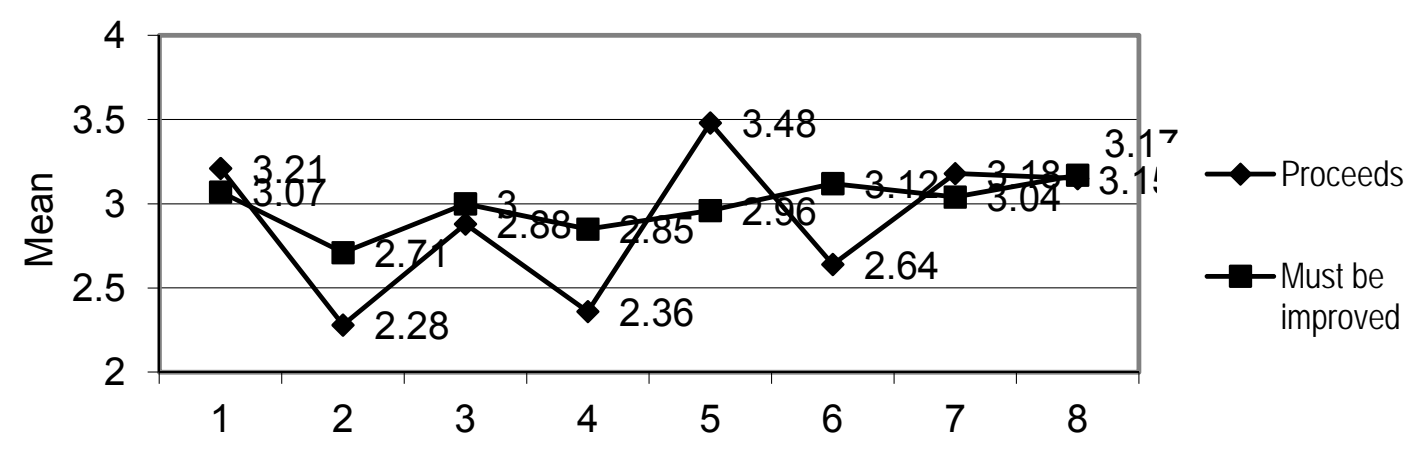

1. Teacher gives time for individual support for a pupil with SEN during a lesson

2. Teacher works individually with a pupil having SEN after lessons are over

3. Teacher organises support of peers for pupils having SEN

4. Teacher uses support of volunteers (parents, foster parents, relatives) in a classroom

5. Teacher, when educating a SEN pupil, follows recommendations of specialists of SCWB and PPS

6. Teacher flexibly arranges education in a classroom according to the need by changing the timetable, using the support of another pedagogue or specialist (special pedagogue, speech therapist) in a classroom

7. Teacher discusses the aims and content of education with a SEN pupil, one's parents

8. Teacher discusses the aims and content of education with a special pedagogue, speech therapist and others

Note: The scale is from 1 to 4

Figure 3 Features of teacher's support in a special class 
The biggest demand for changes was recorded in the following fields: a teacher uses support of volunteers (parents, foster parents, relatives or others) in a classroom (difference between means is 0.49); a teacher flexibly arranges education in a classroom according to the need by changing timetable, using other pedagogue's or specialist's (special pedagogue, speech therapist) support in a classroom (0.46); a teacher works individually with a child having SEN after lessons are over (0.43). The tendencies of the demand for changes that have been identified are similar to those found out when analysing education of pupils in a mainstream school class together with peers.

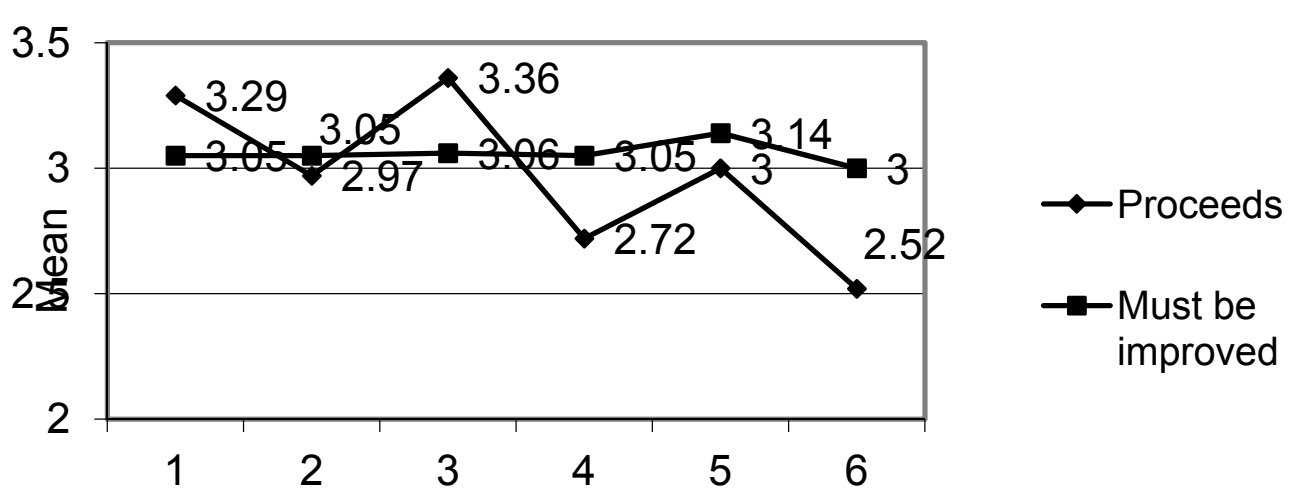

1. Specialist organises group lessons for SEN pupils in a separate room

2. Special pedagogues provide individual support in a separate room during lessons

3. Speech therapist provides individual support in a separate room not during lessons

4. Specialist provides support for SEN children during lessons in a classroom which they attend

5. Specialist flexibly changes one's forms and intensity of support depending on a situation

6. Speech therapist offers support in a classroom during lessons

Note: The scale is from 1 to 4

Figure 4 Features of support of special education specialists for pupils being educated in special classes

Support of professionals of special education. As professionals maintain, there is well-developed special pedagogical support in a separate room. However, pedagogues expressed greater demand for support in a classroom as they wish more support of specialists during lessons for children having SEN in a classroom which they attend (difference between means is 0.33 ); also, a speech therapist could provide support in a classroom during lessons (0.48). This shows the demand for a higher flexibility when applying more diverse strategies of provision of special pedagogical support (see Figure 4).

\section{Education of Pupils in a Special School}

\section{Suitability of education in a special school}

Pedagogues indicated education in a special school as the most suitable form in the cases when very severe ( $70 \%$ of all answers) and severe (58\% of answers) 
SEN are assessed. Pedagogues more seldom indicate that a special school is suitable for education of pupils having moderate SEN and they much more seldom indicated that it is suitable for pupils with mild SEN. Such opinion of teachers reflects an insufficient level of teachers being informed because it is not related to the official order for meeting pupils' SEN. Recent documents of the Ministry of Education and Science, Lithuania regulate that in special schools ${ }^{10}$ pupils with severe and very severe SEN can be accepted only (but not having mild or moderate SEN).

\section{Features of pedagogical and special pedagogical support in a special school}

Teacher's support in a classroom. When assessing teacher's support in a classroom, respondents expressed a great need to improve the following fields: $a$ teacher uses support of volunteers (parents, foster parents, etc.) in a classroom (difference between means is 0.56) and a teacher organises support of peers for pupils with SEN (0.31) (see Figure 5).

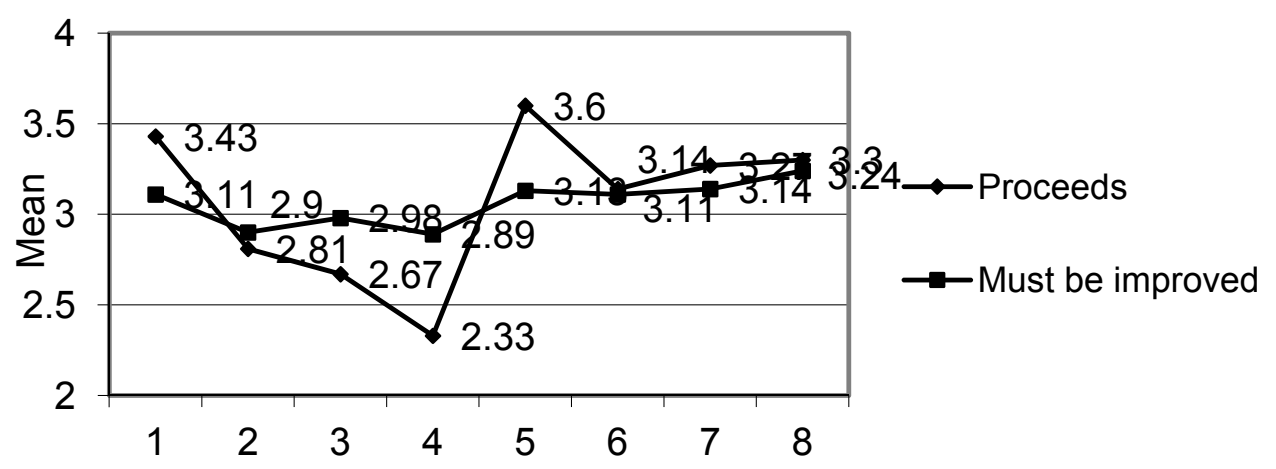

1. Teacher gives time for individual support for a child with SEN during a lesson

2. Teacher works individually with a pupil having SEN after lessons are over

3. Teacher organises support of peers for pupils having SEN

4. Teacher uses support of volunteers (parents, foster parents, relatives and others) in a classroom

5. Teacher, when a educating a SEN pupil, follows recommendations of specialists of SCWB and PPS

6. Teacher flexibly arranges education in a classroom according to the need by changing the timetable,

using the support of another pedagogue of specialist (special pedagogue, speech therapist) in a classroom

7. Teacher discusses the aims and content of education with a SEN pupil, one's parents

8. Teacher discusses the aims and content of education with a special pedagogue, speech therapist and others

Note: The scale is from 1 to 4

Figure 5 Features of teacher's support in a special school

The following features are attributed to support being provided by a teacher in a special school: individualisation of education, the meeting of child's needs with regard to recommendations of specialists, maintenance of relationships with parents and other specialists providing support when discussing the aims and

\footnotetext{
${ }^{10}$ Dèl švietimo ir mokslo ministro 2004 m. birželio 25 d. isakymo Nr. ISAK-1019 "Dèl Prièmimo i valstybine ir savivaldybes bendrojo lavinimo, profesinio mokymo istaiga bendruju kriteriju sarašo patvirtinimo" pakeitimo Valstybès žinios: 2011-07-23 Nr.96-4533.
} 
content of education. Also, they acknowledge that pedagogues not always search for and use all possible resources, i.e. support of peers and volunteers (parents, foster parents, relatives or others) in a classroom.

\section{Features of professionals' support.}

A distinctive feature of a special school means that almost all teachers working at school have a special pedagogue's qualification. However, even in this case additional support is often provided by a speech therapist or other professional (teacher for children with hearing /visual impairment). When assessing support of other specialists, respondents singled out the following main consolidated fields of performance in a special school: a speech therapist offers support in a classroom during lessons (difference between means is 0.45), a specialist provides support to SEN children during lessons in a classroom which they attend (0.23). The research results show that the demand for direct support of specialists in a classroom is relevant too.

\section{Conclusions}

1. In the documents regulating the meeting of SEN in Lithuania, the diverse methods and forms of education of children are discussed and legitimised in the context of inclusive education. When assessing and meeting SEN of pupils, learning needs, including special needs as well, are emphasised, the needs and competences of other participants of the educational process (parents, pedagogues and professionals) are underlined too.

2. The diversity of respondents' opinions towards different forms of education was estimated. Respondents indicate education of pupils having SEN in a comprehensive mainstream school's common class as the most suitable for pupils having mild SEN, partly suitable for pupils having moderate SEN. Education of pupils with more severe SEN is linked to specialised institutions. According to the research participants, education in a special class of a mainstream school is the most suitable for pupils with moderate and severe SEN. According to the respondents, a special school is acknowledged as an educational institution which meets pupils' severe and very severe SEN best. As the respondents hold, the possibility to provide various support and education meeting pupils' needs as well as institution's orientation to vocational training and development of practical skills are the major advantage of a special school.

3. Respondents' opinion on teacher's support to a child in a comprehensive mainstream school's class showed, that support is oriented towards acknowledgement of child's individuality, acceptance of responsibility for pupil's education results and individualisation of education. Teachers acknowledge their essential role in meeting SEN of children. However, not always they receive needed methodological and counselling support 
helping to successfully implement educational aims. The need to identify and to use resources (i.e. volunteering and specialists' support to a class teacher, involvement of a family member, teamwork) is one of the opportunities to develop and improve teacher's support to a child in a comprehensive classroom.

4. When providing special pedagogical support in schools, traditional forms of support (work of a special pedagogue and a speech therapist in a special room, individual work with a child) dominate. The child and other participants of education are insufficiently involved into the educational process; there is too frequent orientation towards single-direction support to the child (a child is estimated as an object of support), towards assessment and "correction of a disorder".

5. According to the respondents, in various types of institutions the individual and group support of professionals for children with SEN in a separate room is well-developed. The demand to make provision of special pedagogical support more efficient in comprehensive mainstream school by making it closer to a child in a classroom, i.e. applying more flexible models of provision of special pedagogical support, more flexibly adjusting forms of special pedagogical support, applying more diverse strategies for organisation of support with regard to a particular educational situation, is expressed.

\section{Summary}

Lithuania's way towards inclusive educational practice is proven by an increasing part of pupils with SEN educating in mainstream comprehensive schools: in academic year 2011-2012, 11.3\% of children having SEN were a part of comprehensive mainstream schools population of Lithuania. Most (over 90\%) of pupils with SEN attended mainstream schools. Special schools and special classes were attended by approx. 10\% of SEN pupils. The presented article is focused on pedagogical and special pedagogical support provided at school for pupils with SEN with the aim to reveal the features of pedagogical and special pedagogical support for pupils with SEN as well as to assess the demand for changes in the mentioned field on the ground of the survey of Lithuanian pedagogues and professionals providing pedagogical and special pedagogical support (the research sample consisted of 1518 respondents). In Lithuania, ideas of inclusive education are implemented by applying a versatile, diverse in educational forms model to meet SEN, structural parts of which should be expand and complement each other. The results of the research allow us to conclude, that meeting of SEN in Lithuania implementing the diverse methods and forms of education are legitimised in the context of inclusive education. Respondents' opinion on teacher's support to a child in a mainstream school's class showed, that support is oriented towards acknowledgement of child's individuality, acceptance of responsibility for pupil's education results and individualisation of education. The need to identify and to use resources is one of the highlighted opportunities by the respondents to develop and improve teacher's support to a child in a comprehensive classroom. Despite the 
positive changes in education towards inclusion, traditional approach when providing special pedagogical support in schools, is still dominating (orientation towards singledirection support to the child and "correction of a disorder"). The demand to make provision of special pedagogical support more efficient in mainstream school by making it closer to a child in a classroom, i.e. applying more flexible models of provision of special pedagogical support, more flexibly adjusting forms and applying more diverse strategies for organisation of support with regard to a particular educational situation, is expressed. Support should be provided more often in a common context of a classroom by making it closer to child's needs in an actual setting.

It is relevant to provide high quality special pedagogical support along with the decrease of its exceptionality and exclusion of SEN pupils in a mainstream school. Education in a comprehensive mainstream school's special classroom should exceed boundaries of a classroom and school by purposefully planning and encouraging social integration, making interactions with children of the same school's other classes and peers of other schools more active via extra-curriculum activities, organisation of leisure time and other everyday activities. It is necessary to consolidate the following activities which are important to inclusive education: support of professionals to a family, support of volunteers in a classroom, involvement of a family, involvement of peers when providing support to a child having SEN, etc.

\section{Bibliography}

1. Ainscow, M. (2005). Understanding the Development of Inclusive Educational System. Electronic Journal of Research in Educational Psychology, 3 (3), 5-20.

2. Ainscow, Booth, Dyson (2006). Improving Schools, Developing Inclusion. London, NY: Routledge.

3. Ališauskas, A., Ališauskienè, S., Gerulaitis, D., Kaffemanienè, I., Melienė, R., Miltenienè, L. (2011). Specialiuju ugdymo(si) poreikiu tenkinimas: Lietuvos patirtis užsienio šalių kontekste. Vš Š ŠU leidykla.

4. Ališauskienè, S.,Miltenienè, L. (2004). Bendradarbiavimas tenkinant specialiuosius ugdymosi poreikius: mokomoji knyga. V̌̌̆ ŠU leidykla.

5. Avramidis, E., Bayliss, P., Burden, R. (2000). Student teachers' altitudes towards the inclusion of children with special educational needs in the ordinary school. Teaching and Teacher Education, 16, 277- 293.

6. Florian, L. (2009). Towards inclusive pedagogy. In P. Hick, R. Kershner\& P. Farrell (Eds.). Psychology for Inclusive Education: new directions in theory and practice, pp. 38-51. London: Routledge Falmer.

7. Kershner, R. (2009). Learning in inclusive classrooms. In P. Hick, R. Kershner \& P. Farrell (Eds.). Psychology for Inclusive Education: new directions in theory and practice, pp. 52-65. London: Routledge Falmer.

8. LR Švietimo ịstatymo pakeitimo įstatymas (2011).2011 m. kovo $17 \mathrm{~d}$. Nr. XI-1281, Vilnius. Access via the Internet http://www3.lrs.lt/pls/inter2/dokpaieska.showdoc_1?p_id=395105.

9. Meijer, C. J. W. (Ed.). (2003). Inclusive Education and Classroom Practice Summary Report. Access via the Internet at: http://www.europeanagency.org/publications/ereports/inclusive-education-and-classroompractices/iecp-en.pdf. 
10. Miltenienė L. (2005). Bendradarbiavimo realybė tenkinant vaiko specialiuosius ugdymosi poreikius bendrojo lavinimo mokykloje. Specialusis ugdymas, 2 (13), 34-44.

11. Miltenienè, L. (2006). Mokyklos vadovų nuostatos ị specialiujų ugdymosi poreikių mokinių integruotą ugdymą. Specialusis ugdymas, 2 (15), 19-26.

12. O`Callaghan, I. (2000). Role of Resource Centres in the Integration of SEN Students. In Rodrigues, D. (ed.). School and Integration in Europe: Values and Practices. Lisbon: SPCE.

13. Savolainen, H., Engelbrecht, P., Nel, M. \&Malinen, O. (2011). Understanding teachers' attitudes and self-efficacy in inclusive education: implications for pre-service and inservice teacher education. European Journal of Special Needs Education. DOI:10.1080/0188563157.2011.613603.

14. Terzi, L. (2008). Justice and Equality in Education: a capability perspective on disability and special educational needs. London: Continuum International Publishing Group.

15. UNESCO (2009a). Policy Guidelines on Inclusion in Education. Access via the Internet at: http://unesdoc.unesco.org/images/0017/001778/177849e.pdf.

16. UNESCO (2009b). International Conference on Education 48th session, Geneva, Switzerland. 25-28 November 2008. „Inclusive Education: the Way of the Future“. Final Report. Access via the Internet at:

http://www.ibe.unesco.org/fileadmin/user upload/Policy Dialogue/48th ICE/ICE FINA L REPORT eng.pdf

\begin{tabular}{|c|l|}
\hline Algirdas Alisauskas & $\begin{array}{l}\text { Siauliai University } \\
\text { Lithuania } \\
\\
\text { Email: alg_ali@cr.su.lt }\end{array}$ \\
\hline Stefanija Alisauskiene & Siauliai University \\
& Lithuania \\
& Email: $\underline{\text { s.alisauskiene@,cr.su.lt }}$ \\
\hline Lina Milteniene & Siauliai University \\
& Lithuania \\
& Email: $\underline{\text { m.lina@cr.su.lt }}$ \\
\hline
\end{tabular}

